\title{
Festa Literária no Colégio Estadual do Rio Grande do Norte
}

\section{Literary Festival at Rio Grande do Norte State School}

Fiesta Literaria en la Escuela Estadual de Rio Grande del Norte

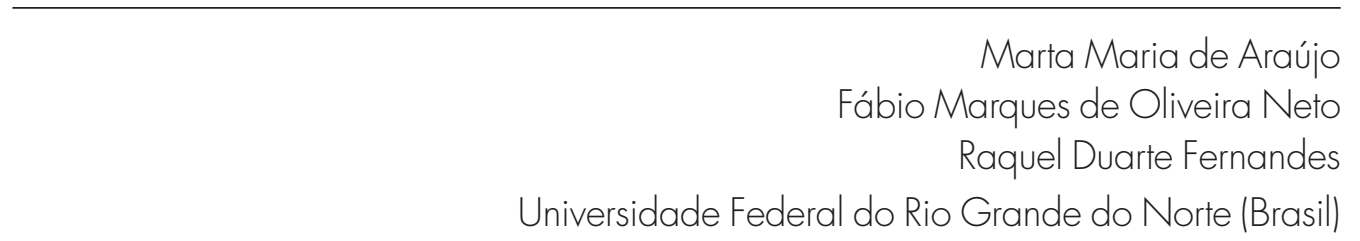

CONFERẾNCIAS no Colégio Estadual. Natal: Sebo Vermelho Edições, 2012 (1 ${ }^{a}$ série).

Em 1943, o diretor do Colégio Estadual do Rio Grande do Norte (hoje Colégio Estadual do Atheneu Norte-Riograndense), o professor Alvamar Furtado de Mendonça (com apenas 28 anos de idade), promoveu o I Curso de Conferências, reunidas num livro impresso nas oficinas de "O Diário", nesse mesmo ano. Após sessenta e nove anos de sua publicação, o Editor Abimael Silva, do Sebo Vermelho, lançou, em 2012, uma edição fac-similar da primeira série (com orelha escrita pelo jornalista Vicente Serejo), formada por um conjunto de quatro palestras lidas entre 10 de julho e 5 de agosto de 1943.

Para cada uma das falas de professores e de escritores, havia uma apresentação por um professor titular do Colégio, cabendo ao professor Alvamar Furtado pronunciar a palestra de abertura, justificando esse I Curso de Conferências como sendo uma preparação intelectual da mocidade estudantil para a construção dos tempos futuros que se seguiriam após a Segunda Guerra Mundial (1939-1945). A resenha dessa edição fac-similar justifica-se pela defesa intransigente daqueles professores e escritores de um mundo distinto entre homens e mulheres altivos, cultos, corajosos, honestos, solidários, sensíveis que promoveriam a elevação de uma sociedade igualitária e igualmente justa para toda a humanidade, um ideal muito próximo das nossas lutas e das nossas defesas dos dias atuais que correm no Brasil. 
A primeira palestra, "Retrato de uma hora de transição", proferida pelo professor Rivaldo Pinheiro, inaugurou o I Curso de Conferências do Colégio Estadual do Rio Grande do Norte na noite de 10 de julho de 1943. A palestra versava sobre a fase presente da existência humana, apresentando-a como um labirinto de problemas profundos e complexos, difíceis de ser resolvidos devido à prevalência dos princípios clássicos de vida em comum e das relações econômicas vigentes. Apesar do desnível econômico universal e do choque de ideologias de ordem social e política, havia a sinalização do início de uma nova fase para a juventude estudantil.

Nessa hora de transição, o professor Rivaldo Pinheiro almejava que a mocidade estudantil do Colégio Estadual do Rio Grande do Norte fosse conduzida por um regime de confiança íntima e recíproca, de congraçamento, de honestidade e de independência em suas atitudes. Além disso, primava pelo incentivo à inteligência investigadora e criadora, que levaria os jovens ao desempenho de funções e de atividades legítimas de paz e de tranquilidade no organismo social.

A segunda palestra, "Conversa sobre Anatole France", proferida pelo escritor Antonio Pinto de Medeiros, na noite de 17 de julho de 1943, homenageava o escritor Anatole François Thibault, nascido em 16 de abril de 1844, em Paris, cujo centenário de nascimento transcorreria no ano seguinte. De formação clássica, Anatole France, de "alma universal" e prêmio Nobel de Literatura em 1921, escreveu livros renomados como $\bigcirc$ crime de Silvestre Bonnard (1881), A pedra branca (1905), A llha dos Pinguins (1908), A vida de Joana D'Arc (1908), A revolta dos Anjos (1914), entre outros mundialmente conhecidos e reconhecidos.

Para o escritor Antonio Pinto de Medeiros (2012, p. 55), as obras clássicas do pensador Anatole France trazem "[...] as mais variadas ideias sobre as paixões, os homens do passado e a história". A sua palestra tinha como principal intento despertar naquela mocidade estudantil, o poder mágico e o encanto das palavras constantes nas obras de Anatole France. $O$ contato com Anatole France - revelou, na ocasião, o palestrante - permite que aprendamos que o riso e a tolerância são raízes da sabedoria da vida e, com eles, se soergueria o mundo.

A terceira palestra, "Presença de alguns mortos", proferida pelo professor João Wilson Mendes Melo, na noite de 24 de julho de 1943, foi pautada 
na constatação de que as ações hodiernas eram uma continuação de tudo o que as gerações dos séculos anteriores produziram.

$\bigcirc$ palestrante, recorrendo a pensadores modernos como Alfonse Daudet, Anatole France, Dante Alighieri, Antero de Quental, Miguel de Cervantes, Stefan Zweig, Augusto dos Anjos, Humberto de Campos, Olavo Bilac e outros, conclamava seus alunos para que, "[... inspirados pelos exemplos destes que vivem e viverão sempre presentes em algum homem e em cada momento, [pudessem] fugir um pouco da sufocante idéia de aniquilamento das nossas forças pelo barbarismo da época". (p. 79). Segundo seu entendimento, a condição essencial para o êxito das novas gerações era a consciência exata, a noção perfeita das proporções da luta aliada à proporção de todas as forças para a elevação das ideais que as guiavam humanamente. Também acreditava que, apesar daquela época de Guerra Mundial, já era um tempo de vultosas ideias e ideais para a prática perene do bem que não havia de faltar para aquela geração jovem do Colégio Estadual do Rio Grande do Norte.

A quarta palestra, "Lembrança de Zaratustra", proferida pelo professor Luiz Maranhão Filho, encerrava essa primeira série na noite de 5 de agosto de 1943. Em "Assim falou Zaratustra", do filósofo alemão Friedrich Nietzsche, o palestrante apresentou Zaratustra que, em suas parábolas e em seus sermões, revelava um espírito luminoso, cheio de arrojados voos pelas regiões longínquas do pensamento e de ideias contraditórias que o atraía e o encantava.

Para o professor Luiz Maranhão Filho, na obra de Nietzsche, "Zaratustra", constrói-se o encanto deslumbrante de todas as nuances "[...] que nos leva a um estado de espírito quase sublime, em que as vozes interiores se desprendem do ser para a suprema procura da harmonia" (p. 92). A obra em destaque, por sua grandiosidade, é deveras inspiradora de ideais filosóficos, artísticos, religiosos e dialéticos da vida espiritual e material.

A primazia do filósofo Friedrich Nietzsche, na inquietação dos tempos modernos, provavelmente, seria, para o professor Luiz Maranhão Filho, uma inferência da sua maneira veemente de pensar e de escrever. Em relação à História, o seu nome representava, para um movimento revolucionário, o mesmo que representou o filósofo Jean-Jaques Rousseau para a Revolução Francesa.

Mas, naquele tempo de confrontos decisivos, não havia como não se voltar para a preparação do espírito de luta daquela juventude estudantil, 
para a vitória dos ideais humanos. Depois, então, como dizia o professor Luiz Maranhão Filho (2012, p. 106), para os seus jovens alunos, "[...] quando não mais houver sombras de luta [da Grande Guerra com suas misérias inenarráveis], voltaremos a pensar no riso e na tolerância".

Era, de fato, dessa maneira, com o riso e com a tolerância, que se poderia soerguer o mundo de direitos igualitários.

Profa. Dra. Marta Maria de Araújo Universidade Federal do Rio Grande do Norte (Brasil) Departamento de Fundamentos e Políticas da Educação Programa de Pós-Graduação em Educação

Líder do Grupo de Pesquisa Estudos Históricos Educacionais (UFRN/CNPq) Líder do Grupo de Pesquisa Interinstitucional Educação de Mulheres nos Séculos XIX e $X X$ Grupo de Pesquisa História da Educação, Memória e Sociedade (GEGHEMES) E-mail:martaujo@vol.com.br

Doutorando Fábio Marques de Oliveira Neto Universidade Federal do Rio Grande do Norte (Brasil) Programa de Pós-Graduação em Educação Grupo de Pesquisa Estudos Históricos Educacionais (UFRN/CNPq) E-mail: fabiomarques@watfordnatal.com.br

Graduanda Raquel Duarte Fernandes Curso de Pedagogia Universidade Federal do Rio Grande do Norte (Brasil) E-mail: raquel6@hotmail.com

Recebido 18 set. 2018 Aceito 11 out. 2018 